\title{
Influence of Authentic Leadership on Unethical Pro-Organizational Behavior: The Intermediate Role of Work Engagement
}

\author{
Tomasz Gigol『 \\ Institute of Management, SGH Warsaw School of Economics, ul. Madalińskiego 31/33, 02-554 Warszawa, Poland; \\ tgigol@sgh.waw.pl \\ Received: 7 January 2020; Accepted: 5 February 2020; Published: 6 February 2020

\begin{abstract}
Business ethics are an important part of corporate sustainability. Sustainability concerns not only the environment but also the well-being of employees, which includes work engagement. Authentic leadership has an impact on the work engagement and well-being of subordinates. The aim of the current research is to present the interdependencies between leadership, work engagement, and unethical pro-organizational behavior. A group of 623 employees from various organizations working in various positions in Central and Eastern Poland was surveyed. The relationships between the variables were analyzed using CB-SEM structural modeling methods. The estimation was completed on the basis of the highest probability method. The CB-SEM model was applied in order to verify the hypotheses that had been formulated. The current paper presents an intermediate role of work engagement between supervisors' leadership and the unethical pro-organizational behavior of subordinates. The survey shows that authentic leadership induces subordinates to engage in unethical pro-organizational behavior. Practical implications were formulated, including company board greater integration of ethics into the core values of organizations and emphasis on learning business ethics in universities and MBA studies.
\end{abstract}

Keywords: sustainable development; unethical pro-organizational behavior; authentic leadership; work engagement

\section{Introduction}

The concept of sustainability pertains not only to the economy, natural resources, and environmental impacts but also the labor environment and its impact on the well-being of employees [1,2]. The consideration of sustainability leads to the formation of healthy organizations in which management, culture, and organizational climate create an environment that is conducive to both physical and mental well-being of employees as well as organizational efficiency [3]. As a result, in the area of human resource management, sustainable development means focusing on the well-being of individuals within the organization [1,4]. In a survey conducted by Rego et al. [5], approximately $40 \%$ of chief executive officers (CEOs) listed the environment and employees as key areas of activity that they consider during corporate sustainability planning.

The researchers have recognized the impact of organizational leadership on sustainability [6]. The term "sustainable leadership" has been broadly defined and is characterized by its focus on a vision connecting companies with society, business ethics behavior, corporate social responsibility, innovation, stakeholder engagement and support, and systemic change [7]. The concept of sustainable human capital leadership has also been proposed [4] and an attempt has even been made to conceptualize "healthy leadership" [8]. Vila-Vázquez et al. [9] noted that leadership affects the well-being of employees by increasing their commitment to work. Developing employees in a positive organizational climate 
of trust and ethics is considered one of the most important management practices for sustainable development [5]. The desired characteristics of sustainability leaders include inspiring vision, energizing, and setting an example for subordinates [5].

The leadership theories related to organizational sustainability and sustainable human resources management (HRM) practices distinguish authentic leadership [10]. Metcalf and Benn [11] state that authentic, ethical, and transformational leadership are directly or indirectly related to company sustainability. Authentic leadership has a strong impact on the well-being of employees [12,13]. An authentic leader influences subordinates through social identification, social learning, and social contagion [14]. Consequently, authentic leadership positively impacts subordinate satisfaction $[13,15,16]$. Moreover, authentic leadership increases subordinate satisfaction and happiness [17] and functions in nonprofit workplaces and professions such as nursing [18] as well as in nonprofit organizations [19].

Sustainable management of an organization increases employee work engagement [9], which is an indicator of employee well-being [20] and it is defined as "the state of individuals' mental, physical, and general health, as well as their experiences of satisfaction both at work and outside of work" [21]. Work engagement is considerably different from workaholism and does not lead to professional burnout [22]. Well-being is the fundamental result of sustainable human resource management [1,4].

Furthermore, ethics are integral characteristics of sustainable management [23]. Ethics serve as an important management practice in sustainable development [5]. In terms of attainment of higher goals, an ethical approach to the limits of sustainable development constitutes the natural will to develop an organization. The values behind ethics, such as not exploiting resources at the expense of future generations, indicate that development is still important but not at any cost. An increasing number of companies are addressing ethical issues using institutionalized processes [24]. To this end, companies devise corporate codes of ethics that indicate which activities undertaken on behalf of the company are ethical and which are not. Therefore, it has been decided to present, in this article, the correlations among authentic leadership, work engagement, and involvement in unethical behavior displayed on behalf of an organization. It seems interesting to answer the questions whether and how authentic leadership, which has a very important ethical component, influences employee unethical pro-organizational behavior $[25,26]$; whether authentic leadership increases employee work engagement; and-first and foremost-whether such engaged employees are not more inclined to unethical pro-organizational behavior.

\section{Literature Review}

\subsection{Authentic Leadership}

Leadership plays an important role in management because it engages people around shared goals and values. The core of the theory of authentic leadership is the concept of authenticity that is an expression of activity consistent with the true inner self [27].

Authentic leaders are most often described as follows:

"Individuals who are deeply aware of how they think and behave and are perceived by others as being aware of their own and others' values/moral perspective, knowledge, and strengths; who are aware of the context in which they operate; and who are confident, hopeful, optimistic, resilient, and high on moral character" [28].

Authentic leaders are characterized by four attributes: internalized moral perspective, relational transparency, self-awareness, and balanced processing [29]. Relational transparency refers to a leader's openness to exchanging information with others, including subordinates, as well as willingness to express one's authentic self to others. An internalized moral perspective is concerned with the internal morality of leaders. They adapt their own behavior to values to which they adhere. Balanced processing consists in the leader actually taking into considerations subordinates' opinions and other significant data prior to making a decision. Self-awareness helps the leader understand how he influences his environment and what he really is like as a person. 
The dimensions of behavior described above complement each other and have optimal explanatory power when considered together [29]. As far as performance is concerned, positive influence of leadership on subordinates and the entire team as well as prosocial behavior has been identified $[14,30]$.

Authentic leadership is described as follows:

A pattern of leader behavior that draws upon and promotes both positive psychological capacities and a positive ethical climate to foster greater self-awareness, an internalized moral perspective, balanced processing of information, and relational transparency on the part of leaders working with followers, all while fostering positive self-development [29] (p. 94).

A review of the existing research highlights the positive effect of authentic leadership on the sense of fulfilment of basic needs by employee groups and on work engagement $[15,16,31]$. Authentic leadership reduces the likelihood of professional burnout and the desire to quit work [32], reduces bullying [33], and helps create an active approach to conflict management in organizations [34]. A link exists between authentic leadership and satisfaction with supervisors [29] and work engagement [13,16,35].

Notably, high correlations exist between authentic leadership and transformational leadership [36,37] and between authentic leadership and ethical leadership [37,38]. They all belong to normative theories of leadership [39], which focus on the leader-follower relationship and raising morals in an organization [40]. Both the theory of ethical leadership and the theory of authentic leadership emerged as a result of calling upon business communities to develop a new, more ethical leadership theory after corruption problems in American corporations at the turn of the 20th and 21st centuries [27]. These theories constitute a development of the concept of transformational leadership [41]. Authentic, ethical, and transformational leadership are directly or indirectly related to company sustainability [11]. Therefore, links between these related leadership theories and unethical organizational behavior is worth examining.

\subsection{Authentic Leadership and Ethical Behavior}

The authors of the concept of authentic leadership presented research results showing that authentic leadership is corelated with the manifestations of moral courage by adherents, fully mediating the influence of authentic leadership on the ethical behavior of followers [42]. Another study proved that authentic leadership helps overcome the temptation to make unethical decisions [43].

Research into authentic leadership and Machiavellianism, which is the opposite of authenticity, yielded different results [44]. When Machiavellianism is high, positive influence of authentic leadership on ethical behavior vanishes [45]. Therefore, why is Machiavellianism, an approach based on the idea that the goal justifies the means, which is completely contrary to sustainable management, inconsistent with the views of some authentic leaders? It seems that part of the answer is the construct of authentic leadership, in which the ethical component is devoid of unambiguous ethical content. It does not state what needs to be done in particular situations [46], and it does not refer to a specific catalogue of values; it is based solely on the leader's listening to their inner self and being authentic about themselves, thus complying with their inner code. Only the component of balanced processing is an indication of how to behave toward one's subordinates. Many leaders and ethics researchers disagree with this approach to leadership ethics, e.g., [47,48]. Price [49] states that ethical issues, and even the content of leadership ethics, are treated too superficially in contemporary leadership theories. According to Nyberg and Sveningsson [50], authentic leadership theory contains an internal contradiction and dissonance between the desires to be an authentic leader and a well-received leader.

Empirical evidence for these theoretical considerations is related to the results of a cross-sectional study of eight approaches to leadership, including authentic leadership, confronted with five Western ethical theories. Different leadership approaches were shown to be consistent with the same ethical theory [51].

\subsection{Authentic Leadership and Unethical Pro-Organizational Behavior}

Umphress and Bingham [25] believe that employees sometimes work in an unethical manner with the intention of contributing to the organization. Based on this conclusion, they created a construct 
they called unethical pro-organizational behavior [UPB]. They defined it as "actions that are intended to promote the effective functioning of the organization or its members (e.g., leaders) and violate core societal values, mores, laws, or standards of proper conduct" [25] (p. 96).

The construct draws upon the theory of social exchange, which embraces social relationships as a system of exchange of (not necessarily material) goods based on the model of economic exchange [52,53]. The second basis of the model of unethical pro-organizational behavior is the theory of social identity, which assumes that people prefer inequalities between groups to defend their social hierarchy and their own position within it, usually favoring the groups to which they belong and discriminating against other groups [54]. The third basis of UPB is the process of neutralization, that is, weakening the power of the existing ethical norms that an individual wishes to violate [55]. Neutralization techniques justify committing a forbidden act and reduce the feeling of guilt by means of various methods of justifying one's behavior. This permits the committing of an unethical act without feeling guilty or responsibility.

Employees neutralize unethical activities caused by social exchange by focusing on their specific role and by identifying with the organization $[25,26]$.

An amoral organizational culture, the moral competence of individuals, and the expected negative consequences related to the result of unethical behavior are external factors influencing the level UPB in the organization. UPB results in negative emotions such as anger and shame and cognitive dissonance resulting from behaving contrary to one's values [25].

The influence of leadership on UPB of subordinates is ambiguous. It was found that involvement of employees in UPB is the lowest when the level of ethical leadership of the superiors is moderate. Both too high and too low level of ethical leadership causes employees' UPB to intensify. The mediator in this study was identification with the superior, which, if high, strengthened the above-mentioned correlation [56].

Other findings demonstrated the impact of transformational leadership on involvement of employees in UPB. Here, the mediator was organizational identification of the subordinates and their moral capacity. The results indicate that if the superiors foster emotional involvement in employees, there is risk that they will be achieving corporate goals in an unethical way [57].

In turn, three US researchers observed the influence exerted by two components of transformational leadership, that is, inspiring motivation and charisma, on intensified unethical pro-organizational behavior among subordinates, which was found to be higher than that in the case of transactional leaders [58].

Review of the relevant literature regarding the ambiguity of the results of studies on the correlations between leadership and UPB led us to formulate the following hypothesis:

Hypothesis 1: No relationship exists between supervisor's authentic leadership and the unethical pro-organizational behavior of subordinates.

\subsection{Authentic Leadership and Work Engagement}

Work engagement is understood in many ways. Shuck [59], based on analysis of the literature, identified four approaches to engagement in work-satisfying a need, an antidote to burnout, a combination of satisfaction and engagement, and a multidimensional approach. Kahn [60] believed that work engagement is a relationship between identity and a person's professional role. Britt [61] stated that engagement is a sense of responsibility for one's work. Maslach et al. [62] argued that engagement is the extreme opposite of professional burnout. Another approach to engagement in work is that it is an "individual's involvement and satisfaction as well as enthusiasm for work" [63] (p. 269).

It's adopted the definition of work engagement as an antithesis of professional burnout: "engagement is defined as a positive, fulfilling, work-related state of mind that is characterized by vigor, dedication, and absorption" [64] (p. 74). Vigor is perceived as the experience of a high level of energy and readiness for trying at work. It is also associated with the willingness to do the work entrusted, even in the face of obstacles and difficulties. Dedication to work is an enthusiastic approach 
and a sense of importance and pride. Absorption is a state of increased concentration and commitment to work while retaining the ability to stop it. A committed worker can work for a long time, enjoys the job, and does not succumb to workaholism or burnout [20].

Leadership is a factor that significantly impacts work engagement because leaders create healthy working environments where employees are motivated and satisfied with the way they work [65]. The work engagement of a subordinate is a mediator between supervisors' authentic leadership and the performance of tasks by subordinates [66]. Subordinates engage in work as a result of a leader's sense of promotion of autonomy and a desire to reciprocate to a superior [67]. The influence of authentic leadership on engagement is achieved through relational identification and positive emotions [68], including trust in the supervisor [69]. Research has confirmed the influence of authentic leadership exercised by supervisors on the engagement of subordinates, e.g., [13,15,16,35]. Therefore, we formulated the following hypothesis:

Hypothesis 2: Authentic leadership affects work engagement of followers.

\subsection{Work Engagement and Unethical Pro-Organizational Behavior}

People with a high level of job satisfaction (a concept that is often interrelated with work engagement) have been found to be more willing to engage in unethical pro-organizational behavior through the sense of belonging to the company [70]. Meyer and Herscovitch [71] defined commitment as a force that binds an individual to an objective. It is characterized by the following elements: continuance commitment, normative commitment, and affective commitment. Authentic leadership produces impact on individuals' affective commitment to an organization [72,73].

People with a high level of affective commitment were found to be more likely to engage in UPB [74]. Continuance commitment, which is similar to work engagement, also increases employee involvement in UPB [75]. The results of other studies indicate that normative commitment and affective commitment are predictors of unethical pro-organizational behavior [76].

A strong relationship exists between work engagement and commitment [77]. Commitment is sometimes treated as an element of work engagement $[78,79]$. Therefore, we formulated the following hypothesis:

Hypothesis 3: Work engagement influences unethical pro-organizational behavior.

\subsection{Intermediary Role of Work Engagement between Authentic Leadership and Unethical Pro-Organizational Behavior}

Authentic leadership does not appear to directly impact UPB, but a clear positive impact on the involvement of followers in work, e.g., references $[13,15,16,35]$. As other studies have shown, ethical leadership affects the UPB of followers through continuance commitment as a mediator [75]. Ethical leadership can encourage unethical pro-organizational behavior in followers with low professional autonomy [80]. The subordinates may believe that they only do what the organization wants.

Many correlations exist between ethical and authentic leadership [37]. Theoretical assumptions mention the impact of neutral phenomena such as social exchange on unethical pro-organizational behavior. The above considerations led us to formulate the following hypothesis:

Hypothesis 4: Work engagement is a complete mediator of the relationship between superior leadership and the level of unethical pro-organizational behavior among subordinates working as manual or office workers.

Figure 1 depicts a hypothetical model of the relationships among the variables under examination. We assume that no connection exists between authentic leadership and UPB. It is possible that authentic leadership influences employee work engagement. Among subordinates with low professional autonomy working as manual or office workers, the following dependency path can be observed: 
authentic leadership increases work engagement of followers, and then this work engagement increases the unethical pro-organizational behavior of followers.

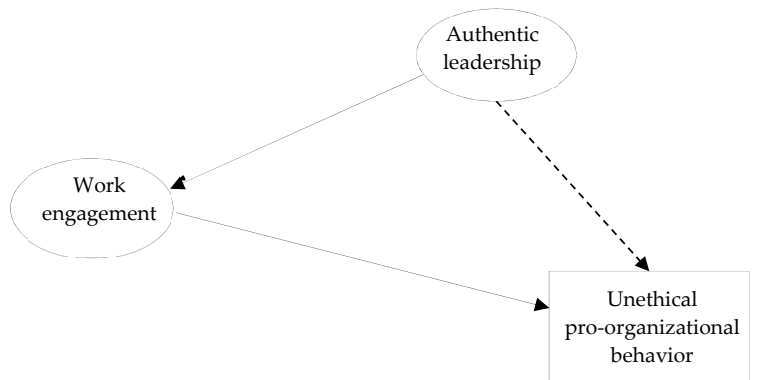

Figure 1. Hypothesized model. The statistically insignificant path is marked with a dashed line.

\section{Data and Methodology}

The respondents were recruited among employees improving their qualifications in part-time and postgraduate studies at three universities in Central and Eastern Poland (two in Warsaw and one in Siedlce). They had the opportunity to participate in the study during their university attendance. We chose the survey method. A research questionnaire was created consisting of a metric and the following questionnaires. The Authentic Leadership Questionnaire (ALQ) [81] was used to examine the authentic leadership of the direct supervisors of the respondents. The questionnaire was validated in Polish [82]. An example of a statement is "My supervisor admits their mistakes to others." Answers were ranked on a five-point Likert scale from 1 (never) to 5 (very often). The survey of the respondents' involvement in work was conducted using the Utrecht Work Engagement Scale (UWES 9) [83], which has been adapted in many countries [84]. The questionnaire consists of 9 questions, and answers are ranked on a seven-point Likert scale from 1 (never) to 7 (every day). An example of a statement is "When I get up in the morning, I feel like going to work". A translated questionnaire on unethical pro-organizational behavior was used [26]. The questionnaire has strong explanatory power and high internal consistency $(\alpha=0.91)$. The questionnaire consists of six statements and uses a seven-point Likert scale ranging from "I strongly disagree" to "I strongly agree." An example of a statement is "If it helped my organization, I would misrepresent the truth to make my organization look good."

The factor structure of the unethical pro-organizational behavior was analyzed with the use of exploratory factor analysis. The scree-plot depicted in Figure 2 revealed unidimensional structure, which explained $55.65 \%$ of total variance.

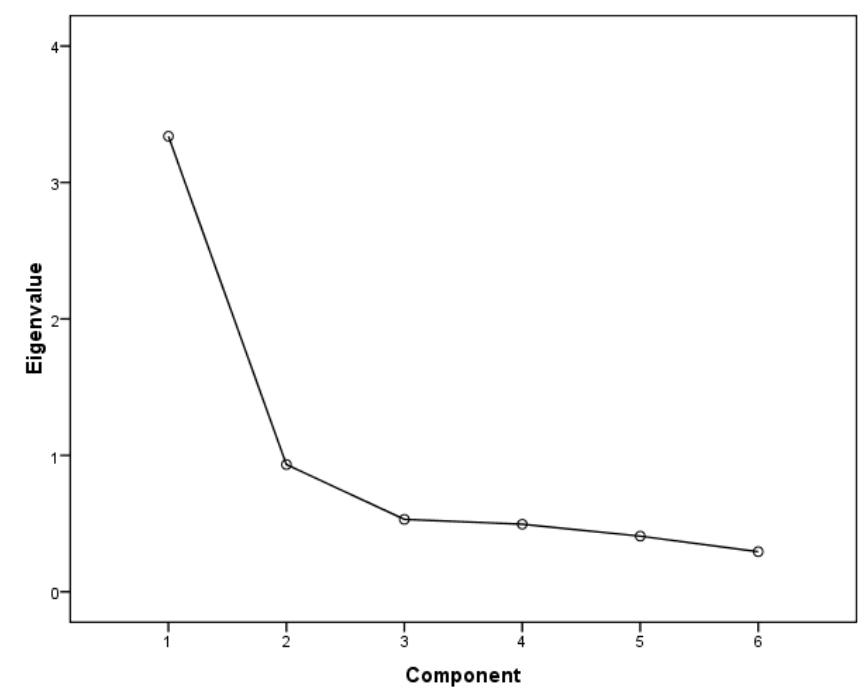

Figure 2. Scree-plot from explanatory factor analysis regarding unethical pro-organizational behavior. 
Table 1 presents acquired factor loadings. All factor loadings 0.5 or greater are considered practically significant [85]. MacCallum et al. [86] proposes, that 0.6 is the minimum level, provided that the average of all factor loadings exceeds 0.7 . Presented study meets this condition. According to Comrey and Lee [87] 0.63 is very good level, and 0.71 is very high. Unethical pro-organizational behavior was analyzed as a unidimensional concept in subsequent analysis.

Table 1. Factor loadings acquired in the exploratory factor analysis of unethical pro-organizational behavior.

\section{Item No.}

3. If it would benefit my organization, I would withhold negative information about my company or its products from customers and clients.

\begin{tabular}{ll}
$\begin{array}{l}\text { 2. If it would help my organization, I would exaggerate the truth about my company's } \\
\text { products or services to customers and clients. }\end{array}$ & 0.80 \\
\hline $\begin{array}{l}\text { 6. If needed, I would conceal information from the public that could be damaging to my } \\
\text { organization. }\end{array}$ & 0.78 \\
\hline $\begin{array}{l}\text { 1. If it would help my organization, I would misrepresent the truth to make my } \\
\text { organization look good. }\end{array}$ & 0.74 \\
\hline $\begin{array}{l}\text { 4. If my organization needed me to, I would give a good recommendation on the behalf } \\
\text { of an incompetent employee in the hope that the person will become another } \\
\text { organization's problem instead of my own. }\end{array}$ & 0.67 \\
\hline $\begin{array}{l}\text { 5. If my organization needed me to, I would withhold issuing a refund to a customer or } \\
\text { client accidentally overcharged. }\end{array}$ & 0.66 \\
\hline
\end{tabular}

The data were subjected to statistical analysis. The relationships between the variables were analyzed using CB-SEM structural modeling methods. IBM SPSS Amos 25.0.0 was used (Amos Development Corporation, 3000 Village Run Road Unit 103, \#315, Wexford, PA 15090, USA). The estimation was completed on the basis of the highest probability method. The CB-SEM model was applied in order to verify formulated hypotheses.

\section{Results}

\subsection{Respondents}

We examined the responses of 623 persons—specifically, 419 women and 204 men. The majority of the respondents (69.7\%) were aged 20-29 years, and 324 had a higher education, while 299 had a secondary education.

Table 2 presents the frequency distribution for the positions occupied by the surveyed persons. The study included 342 persons working in managerial positions or as specialists and 281 persons working as manual or office workers.

Table 2. Frequency distribution of employment positions of the respondents.

\begin{tabular}{ccc}
\hline Position & $\boldsymbol{n}$ & $\mathbf{\%}$ \\
\hline Managerial & 144 & 23.1 \\
\hline Specialist & 198 & 31.8 \\
\hline Manual worker & 100 & 16.1 \\
\hline Office worker & 181 & 29.1 \\
\hline Total & 623 & 100 \\
\hline
\end{tabular}

Table 3 presents the frequency distribution for the period of employment of the respondents. Most people worked for up to three years. 
Table 3. Frequency distribution of positions occupied by respondents.

\begin{tabular}{ccccccc}
\hline Position & Manager or Specialist & \multicolumn{2}{c}{ Manual Worker or Office Worker } & \multicolumn{2}{c}{ Total } \\
\hline & $\boldsymbol{n}$ & $\mathbf{\%}$ & $\boldsymbol{n}$ & $\boldsymbol{\%}$ & $\boldsymbol{n}$ & $\mathbf{\%}$ \\
\hline$<3$ years & 180 & 52.6 & 206 & 73.3 & 386 & 62.0 \\
\hline$>3$ years & 160 & 46.8 & 74 & 26.3 & 234 & 37.6 \\
\hline No data & 2 & 0.6 & 1 & 0.4 & 3 & 0.5 \\
\hline Total & 342 & 100 & 281 & 100 & 623 & 100 \\
\hline
\end{tabular}

Table 4 presents the frequency distribution for the size of companies at which the surveyed persons worked.

Table 4. Frequency distribution of size of companies at which respondents worked.

\begin{tabular}{ccc}
\hline Number of Employees & $\boldsymbol{n}$ & $\boldsymbol{\%}$ \\
\hline$<9$ & 111 & 17.8 \\
\hline $10-49$ & 168 & 27.0 \\
\hline $50-249$ & 115 & 18.5 \\
\hline 2250 & 229 & 36.8 \\
\hline Total & 623 & 100 \\
\hline
\end{tabular}

\subsection{Analysis of Dependencies between Variables}

The dependencies between the variables were analyzed using structural modeling methods. The estimation was completed on the basis of the highest probability method. We assumed that the leadership characteristics of the supervisor would be important for work engagement and the intensity of unethical behavior. The relationship between a superior's leadership and the intensity of unethical behavior is direct and indirect, with the level of engagement in work being the mediator.

The results are presented in Figure 3. The intergroup differences were also analyzed in the scope of the model of dependence between the analyzed variables. People working in managerial or specialist positions and people working as manual or office workers were compared. The statistically insignificant path is marked with a dashed line in Figure 3. In both groups, superior leadership was a statistically significant positive predictor of work engagement. However, only in the group of subordinates working as manual or office workers did work engagement translate positively into unethical pro-organizational behavior. In the group of people working as manual or office workers, work engagement was a complete mediator between a superior's leadership and the level of UPB. According to Sobel's test, the mediation effect was statistically significant: $Z=2.90, p<0.01$.

In the group of subordinates working as manual or office workers, the supervisor's leadership translated into work engagement and work engagement into unethical pro-organizational behavior. In the group of managers and specialists, however, the supervisor's leadership translated into work engagement. However, we found no statistically significant correlation between the level of work engagement and the level of unethical pro-organizational behavior. Our hypotheses appear to be supported by the results. 


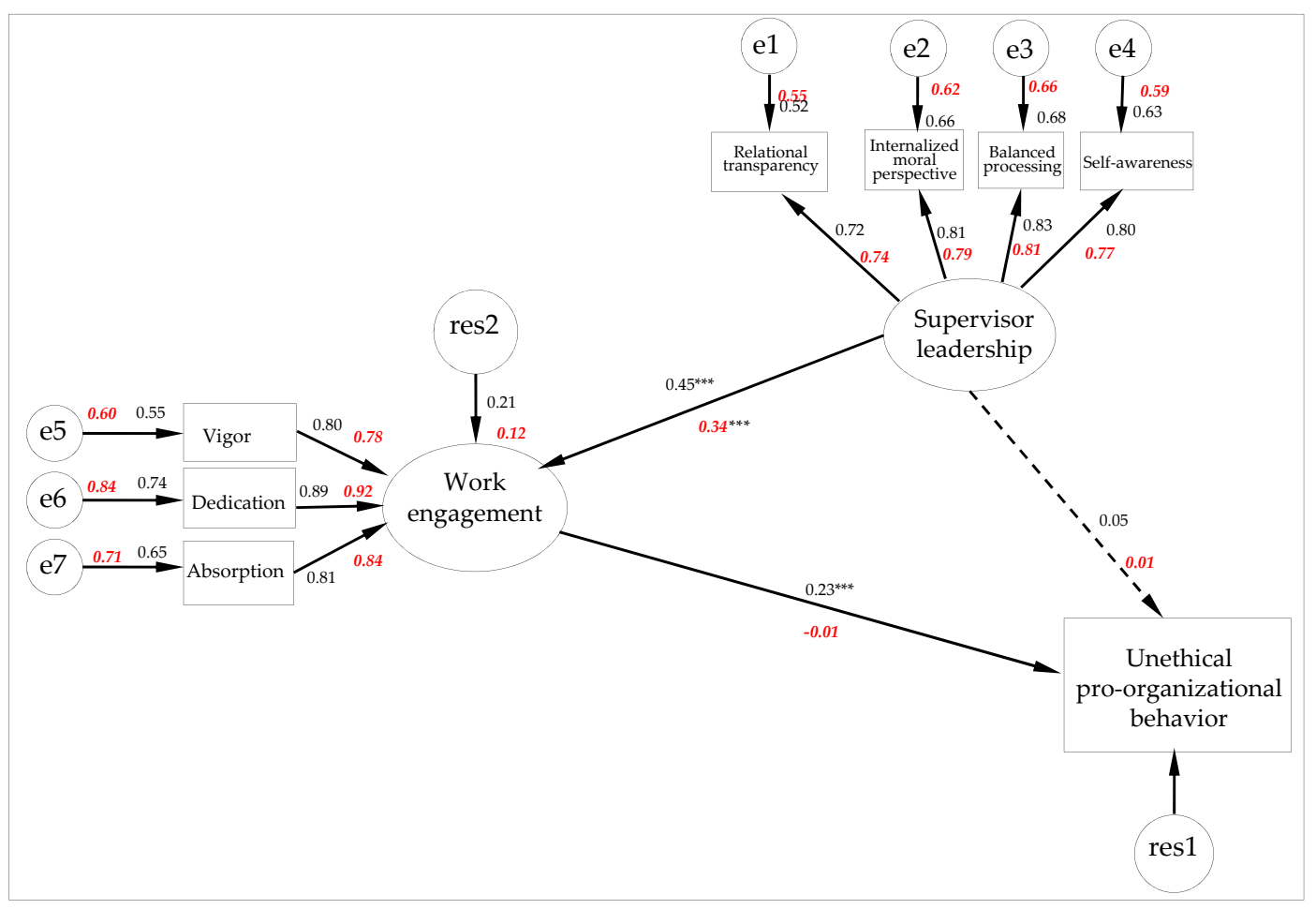

Figure 3. Results of the structural modeling of persons working in managerial or specialist positions and manual or office worker positions (e - measurement error; res-residual.; ${ }^{* * *} p<0.001$ manual or office worker, managers, or specialists).

\section{Discussion}

The results revealed a lack of correlation between authentic leadership and UPB. This means that the ethical component of authentic leadership only requires compliance with the leader's inner self. The findings confirm the theoretical considerations of other authors [47-49], which are also consistent with empirical research on the relationship between leadership and UPB [56-58]. This is the first study to analyze the relationship between authentic leadership and unethical pro-organizational behavior.

The strong influence of authentic leadership on work engagement of followers is reaffirmed for all respondents regardless of their job position. This is yet another confirmation of the usefulness of the theory of authentic leadership in management and its impact on the well-being of subordinates; therefore, it is also a useful theory in sustainability management.

For the first time, the impact of engagement on UPB was studied, and this impact proved to be statistically significant for manual workers and office workers who are not experts or managers. To date, the impact of commitment on UPB has been observed. Notably, the above concepts are vague and partly overlap, which makes it complicated to arrive at clear conclusions. The concept of full engagement may be worth developing, which combines work engagement and well-being [88]. We present further research results that point to the intermediary role of positive social phenomena in the employee-work dyad, which additionally have negative effects on ethical behavior of some groups at work comprising subordinates on basic positions with low professional autonomy.

This result is consistent with the UPB theory [25]. We have not examined which social phenomena directly influence UPB, which might be social exchange or social learning. However, this is another confirmation that, under certain circumstances and under the influence of positive phenomena, some subordinates are prone to unethical pro-organizational behavior. The results correspond to those reported in other studies, e.g., reference [80]. 


\section{Conclusions}

\subsection{Practical Implications}

The negative mediation of work engagement between authentic leadership and the unethical pro-organizational behavior that occurs among subordinates on the simplest positions is puzzling. Perhaps in the course of gaining skills by professionals, autonomy in terms of ethical behavior increases. Current research shows a dangerous aspect of authentic leadership, which can encourage followers working as manual or office workers to participate in unethical pro-organizational behavior. This does not mean that a person should stop practicing authentic leadership but only pay extra attention to learning what is and is not ethically acceptable in an organization. Once organizational values have been determined, ethics should be integrated with the basic values of the organization. When evaluating leaders, however, their ethics should be considered.

According to Miao et al. [56], this survey shows that top level managers should compile codes of ethics that clearly show what is and what is not acceptable in an organization. Such a code of ethics should be consistent with the strategy of an organization and the values it encourages. This will show a clear contradiction with the organization's objectives and discourage the use of unethical practices in their pursuance.

Despite the fact that business ethics courses are provided on MBA studies, they are not often chosen by students. Perhaps they should be compulsory and conducted in the form of practical trainings [89]. The same applies to academic courses on business and management. Finally, the idea of sustainability management in the field of ethical behavior in everyday business work should be disseminated.

\subsection{Limitations and Future Research}

This research and its results have certain limitations. First, the study sample is unrepresentative. It is overrepresents young people under 29 years of age. As a result, people with relatively low seniority were surveyed. As the respondents were all receiving further education, this may also influence interpretation of the results. Another limitation is the fact that the respondents were students. Studying employees may have a different approach to work engagement and UPB. The size of the group was large. We hope that the sample size compensates for the deficiencies.

The differentiation of the results into subordinates working as managers, experts, manual workers and office workers requires further research. Whether this is a variable that differentiates the impact of leadership on UPB could be investigated further. The influence of other leadership theories should be examined, including servant leadership or spiritual leadership, on unethical pro-organizational behavior. An interesting direction of research is also related to a variant of unethical pro-organizational behavior, namely, unethical pro-supervisor behavior [90]. In the future, it is also worth examining whether the dependency between authentic leadership and UPB will differ in organizations that have implemented the CSR strategy and ones that have not implemented such a strategy. An interesting factor moderating this dependency may also be the character of an organization under examination-whether it is a public, commercial, or a commercial state-owned undertaking.

Funding: This research received no external funding.

Conflicts of Interest: The author declares no conflict of interest.

\section{References}

1. Di Fabio, A. The psychology of sustainability and sustainable development for well-being in organizations. Front. Psychol. 2017, 8, 1534. [CrossRef] [PubMed]

2. Wachowiak, P. Społeczna odpowiedzialność biznesu-Wyzwania stojące przed polskimi przedsiębiorstwami. E-Mentor 2011, 41, 23-28. 
3. Di Fabio, A. Positive healthy organizations: Promoting well-being, meaningfulness, and sustainability in organizations. Front. Psychol. 2017, 8, 1938. [CrossRef] [PubMed]

4. Di Fabio, A.; Peiró, J.M. Human capital sustainability leadership to promote sustainable development and healthy organizations: A new scale. Sustainability 2018, 10, 2413. [CrossRef]

5. Rego, A.; Cunha, M.P.E.; Polónia, D. Corporate sustainability: A view from the top. J. Bus. Ethics 2017, 143, 133-157. [CrossRef]

6. Du, S.; Swaen, V.; Lindgreen, A.; Sen, S. The roles of leadership styles in corporate social responsibility. J. Bus. Ethics 2013, 114, 155-169. [CrossRef]

7. Hallinger, P.; Suriyankietkaew, S. Science mapping of the knowledge base on sustainable leadership, 1990-2018. Sustainability 2018, 10, 4846. [CrossRef]

8. Rudolph, C.W.; Murphy, L.D.; Zacher, H. A systematic review and critique of research on "healthy leadership". Leadersh. Q. 2019, 101335. [CrossRef]

9. Vila-Vázquez, G.; Castro-Casal, C.; Álvarez-Pérez, D.; del Río-Araújo, L. Promoting the sustainability of organizations: Contribution of transformational leadership to job engagement. Sustainability 2018, 10, 4109. [CrossRef]

10. Avolio, B.J.; Gardner, W.L. Authentic leadership development: Getting to the root of positive forms of leadership. Leadersh. Q. 2005, 16, 315-338. [CrossRef]

11. Metcalf, L.; Benn, S. Leadership for sustainability: An evolution of leadership ability. J. Bus. Ethics 2013, 112, 369-384. [CrossRef]

12. Ilies, R.; Morgeson, F.P.; Nahrgang, J.D. Authentic leadership and eudaemonic well-being: Understanding leader-follower outcomes. Leadersh. Q. 2005, 16, 373-394. [CrossRef]

13. Rahimnia, F.; Sharifirad, M.S. Authentic leadership and employee well-being: The mediating role of attachment insecurity. J. Bus. Ethics 2015, 132, 363-377. [CrossRef]

14. Gill, C.; Caza, A. An investigation of authentic leadership's individual and group influences on follower responses. J. Manag. 2018, 44, 530-554. [CrossRef]

15. Wang, D.-S.; Hsieh, C.-C. The effect of authentic leadership on employee trust and employee engagement. Soc. Behav. Personal. Int. J. 2013, 41, 613-624. [CrossRef]

16. Penger, S.; Černe, M. Authentic leadership, employees' job satisfaction, and work engagement: A hierarchical linear modelling approach. Econ. Res. Ekon. Istraž. 2014, 27, 508-526. [CrossRef]

17. Jensen, S.M.; Luthans, F. Relationship between entrepreneurs' psychological capital and their authentic leadership. J. Manag. Issues 2006, 18, 254-273.

18. Wong, C.A.; Laschinger, H.K. Authentic leadership, performance, and job satisfaction: The mediating role of empowerment. J. Adv. Nurs. 2013, 69, 947-959. [CrossRef]

19. Mingyuan, L.; Geng, L. A study on the effects of authentic leadership on psychological capital and knowledge sharing in China association for NGO cooperation. Acta Oecon. 2015, 65, 115-129. [CrossRef]

20. Schaufeli, W.B.; Taris, T.W.; Van Rhenen, W. Workaholism, burnout, and work engagement: Three of a kind or three different kinds of employee well-being? Appl. Psychol. 2008, 57, 173-203. [CrossRef]

21. Nielsen, K.; Nielsen, M.B.; Ogbonnaya, C.; Känsälä, M.; Saari, E.; Isaksson, K. Workplace resources to improve both employee well-being and performance: A systematic review and meta-analysis. Work Stress 2017, 31, 101-120. [CrossRef]

22. Schaufeli, W.B.; Taris, T.W.; Bakker, A.B. Dr. Jekyll or Mr. Hyde: On the differences between work engagement and workaholism. In Research Companion to Working Time and Work Addiction; Burke, R.J., Ed.; Edward Elgar Publications Limited: Cheltenham, UK, 2006; pp. 193-217.

23. Wiernik, B.M.; Ones, D.S. Ethical employee behaviors in the consensus taxonomy of counterproductive work behaviors. Int. J. Sel. Assess. 2018, 26, 36-48. [CrossRef]

24. Sroka, W.; Szántó, R. Corporate social responsibility and business ethics in controversial sectors: Analysis of research results. J. Entrep. Manag. Innov. 2018, 14, 111-126. [CrossRef]

25. Umphress, E.E.; Bingham, J.B. When employees do bad things for good reasons: Examining unethical pro-organizational behaviors. Organ. Sci. 2011, 22, 621-640. [CrossRef]

26. Umphress, E.E.; Bingham, J.B.; Mitchell, M.S. Unethical behavior in the name of the company: The moderating effect of organizational identification and positive reciprocity beliefs on unethical pro-organizational behavior. J. Appl. Psychol. 2010, 95, 769-780. [CrossRef] [PubMed]

27. Luthans, F.; Avolio, B.J. Authentic leadership development. Posit. Organ. Scholarsh. 2003, 241, 258. 
28. Avolio, B.J.; Luthans, F.; Walumbwa, F.O. Authentic Leadership: Theory Building for Veritable Sustained Performance; Working Paper; Gallup Leadership Institute: Lincoln, NE, USA, 2004.

29. Walumbwa, F.O.; Avolio, B.J.; Gardner, W.L.; Wernsing, T.S.; Peterson, S.J. Authentic leadership: Development and validation of a theory-based measure. J. Manag. 2008, 34, 89-126. [CrossRef]

30. Gardner, W.L.; Cogliser, C.C.; Davis, K.M.; Dickens, M.P. Authentic leadership: A review of the literature and research agenda. Leadersh. Q. 2011, 22, 1120-1145. [CrossRef]

31. Leroy, H.; Anseel, F.; Gardner, W.L.; Sels, L. Authentic leadership, authentic followership, basic need satisfaction, and work role performance: A cross-level study. J. Manag. 2015, 41, 1677-1697. [CrossRef]

32. Laschinger, H.K.S.; Fida, R. New nurses burnout and workplace wellbeing: The influence of authentic leadership and psychological capital. Burn. Res. 2014, 1, 19-28. [CrossRef]

33. Warszewska-Makuch, M.; Bedynska, S.; Zolnierczyk-Zreda, D. Authentic leadership, social support and their role in workplace bullying and its mental health consequences. Int. J. Occup. Saf. Ergon. 2015, 21, 128-140. [CrossRef] [PubMed]

34. Gigol, T.; Sypniewska, B.A. Interpersonal conflicts in the workplace and authentic leadership-evidence from Poland. JEEMS 2019, 37. [CrossRef]

35. Leroy, H.; Palanski, M.E.; Simons, T. Authentic leadership and behavioral integrity as drivers of follower commitment and performance. J. Bus. Ethics 2012, 107, 255-264. [CrossRef]

36. Banks, G.C.; McCauley, K.D.; Gardner, W.L.; Guler, C.E. A meta-analytic review of authentic and transformational leadership: A test for redundancy. Leadersh. Q. 2016, 27, 634-652. [CrossRef]

37. Hoch, J.E.; Bommer, W.H.; Dulebohn, J.H.; Wu, D. Do ethical, authentic, and servant leadership explain variance above and beyond transformational leadership? A meta-analysis. J. Manag. 2018, 44, 501-529. [CrossRef]

38. Brown, M.E.; Treviño, L.K. Ethical leadership: A review and future directions. Leadersh. Q. 2006, 17, 595-616. [CrossRef]

39. Wren, J.T. A quest for a grand theory of leadership. In The Quest for a General Theory of Leadership; Goethals, G.R., Sorenson, G.L.J., Eds.; Edward Elgar: Northampton, MA, USA, 2006; pp. 1-38.

40. Walker, M.C. The theory and metatheory of leadership: The important but contested nature of theory. In The Quest for a General Theory of Leadership; Goethals, G.R., Sorenson, G.L.J., Eds.; Edward Elgar Publications: Chesterton, UK, 2006; pp. 46-74.

41. Avolio, B.J. Full Leadership Development: Building the Vital Forces in Organizations; Sage: Thousand Oaks, CA, USA, 1999.

42. Hannah, S.T.; Avolio, B.J.; Walumbwa, F.O. Relationships between authentic leadership, moral courage, and ethical and pro-social behaviors. Bus. Ethics Q. 2011, 21, 555-578. [CrossRef]

43. Cianci, A.M.; Hannah, S.T.; Roberts, R.P.; Tsakumis, G.T. The effects of authentic leadership on followers' ethical decision-making in the face of temptation: An experimental study. Leadersh. Q. 2014, 25, 581-594. [CrossRef]

44. Castille, C.M.; Buckner, J.E.; Thoroughgood, C.N. Prosocial citizens without a moral compass? Examining the relationship between Machiavellianism and unethical pro-organizational behavior. J. Bus. Ethics 2018, 149, 919-930. [CrossRef]

45. Sendjaya, S.; Pekerti, A.; Härtel, C.; Hirst, G.; Butarbutar, I. Are authentic leaders always moral? The role of Machiavellianism in the relationship between authentic leadership and morality. J. Bus. Ethics 2016, 133, 125-139. [CrossRef]

46. Flanigan, J. Philosophical methodology and leadership ethics. Leadership 2018, 14, 707-730. [CrossRef]

47. Lawler, J.; Ashman, I. Theorizing leadership authenticity: A Sartrean perspective. Leadership 2012, 8, 327-344. [CrossRef]

48. Gardiner, R.A. Leadership, authenticity, and the Arendtian world. Word Hoard 2012, 1, 8.

49. Price, T.L. A "critical leadership ethics" approach to the ethical leadership construct. Leadership 2018, 14, 687-706. [CrossRef]

50. Nyberg, D.; Sveningsson, S. Paradoxes of authentic leadership: Leader identity struggles. Leadership 2014, 10, 437-455. [CrossRef]

51. Dion, M. Are ethical theories relevant for ethical leadership? Leadersh. Organ. Dev. J. 2012, 33, 4-24. [CrossRef]

52. Blau, P. Power and Exchange in Social Life; John Wiley \& Sons: New York, NY, USA, 1964. 
53. Emerson, R.M. Social exchange theory. Annu. Rev. Sociol. 1976, 2, 335-362. [CrossRef]

54. Tajfel, H.; Turner, J.C. An integrative theory of intergroup conflict. In Organizational identity: A reader; Hatch, M.J., Schultz, M., Eds.; Oxford University Press on Demand: Oxford, UK, 2004; pp. 56-65.

55. Sykes, G.M.; Matza, D. Techniques of neutralization: A theory of delinquency. Am. Sociol. Rev. 1957, 22, 664-670. [CrossRef]

56. Miao, Q.; Newman, A.; Yu, J.; Xu, L. The relationship between ethical leadership and unethical pro-organizational behavior: Linear or curvilinear effects? J. Bus. Ethics 2013, 116, 641-653. [CrossRef]

57. Effelsberg, D.; Solga, M.; Gurt, J. Transformational leadership and follower's unethical behavior for the benefit of the company: A two-study investigation. J. Bus. Ethics 2014, 120, 81-93. [CrossRef]

58. Graham, K.A.; Ziegert, J.C.; Capitano, J. The effect of leadership style, framing, and promotion regulatory focus on unethical pro-organizational behavior. J. Bus. Ethics 2015, 126, 423-436. [CrossRef]

59. Shuck, B. Integrative literature review: Four emerging perspectives of employee engagement: An integrative literature review. Hum. Resour. Dev. Rev. 2011, 10, 304-328. [CrossRef]

60. Kahn, W.A. Psychological conditions of personal engagement and disengagement at work. Acad. Manag. J. 1990, 33, 692-724. [CrossRef]

61. Britt, T.W. Engaging the self in the field: Testing the triangle model of responsibility. Personal. Soc. Psychol. Bull. 1999, 25, 698-708. [CrossRef]

62. Maslach, C.; Schaufeli, W.B.; Leiter, M.P. Job burnout. Annu. Rev. Psychol. 2001, 52, 397-422. [CrossRef] [PubMed]

63. Harter, J.K.; Schmidt, F.L.; Hayes, T.L. Business-unit-level relationship between employee satisfaction, employee engagement, and business outcomes: A meta-analysis. J. Appl. Psychol. 2002, 87, 268-279. [CrossRef]

64. Schaufeli, W.B.; Salanova, M.; González-Romá, V.; Bakker, A.B. The measurement of engagement and burnout: A two sample confirmatory factor analytic approach. J. Happiness Stud. 2002, 3, 71-92. [CrossRef]

65. Asif, M.; Qing, M.; Hwang, J.; Shi, H. Ethical leadership, affective commitment, work engagement, and creativity: Testing a multiple mediation approach. Sustainability 2019, 11, 4489. [CrossRef]

66. Wei, F.; Li, Y.; Zhang, Y.; Liu, S. The interactive effect of authentic leadership and leader competency on followers' job performance: The mediating role of work engagement. J. Bus. Ethics 2018, 153, 763-773. [CrossRef]

67. Hsieh, C.-C.; Wang, D.-S. Does supervisor-perceived authentic leadership influence employee work engagement through employee-perceived authentic leadership and employee trust? Int. J. Hum. Resour. Manag. 2015, 26, 2329-2348. [CrossRef]

68. Malik, M.F.; Khan, M.A. "Tracking engagement through Leader" authentic leadership's consequences on followers' attitudes: A sequential mediated mode. Int. J. Public Adm. 2019, 1-8. [CrossRef]

69. Liu, F.; He, S.; Tang, Y.; Liu, X. The impact of authentic leadership on employees' work engagement: A multilevel study in Chinese hospitality industry. In Proceedings of the 2014 11th International Conference on Service Systems and Service Management (ICSSSM), Beijing, China, 25-27 June 2014; IEEE: Beijing, China, 2014; pp. 1-6.

70. Dou, K.; Chen, Y.; Lu, J.; Li, J.; Wang, Y. Why and when does job satisfaction promote unethical pro-organizational behaviours? Testing a moderated mediation model. Int. J. Psychol. 2018. [CrossRef] [PubMed]

71. Meyer, J.P.; Herscovitch, L. Commitment in the workplace: Toward a general model. Hum. Resour. Manag. Rev. 2001, 11, 299-326. [CrossRef]

72. Peus, C.; Wesche, J.S.; Streicher, B.; Braun, S.; Frey, D. Authentic leadership: An empirical test of its antecedents, consequences, and mediating mechanisms. J. Bus. Ethics 2012, 107, 331-348. [CrossRef]

73. Rego, P.; Lopes, M.P.; Nascimento, J.L. Authentic leadership and organizational commitment: The mediating role of positive psychological capital. J. Ind. Eng. Manag. 2016, 9, 129-151. [CrossRef]

74. Matherne, C.F., III; Litchfield, S.R. Investigating the relationship between affective commitment and unethical pro-organizational behaviors: The role of moral identity. J. Leadersh. Account. Ethics 2012, 9, 35-46.

75. Park, J.G.; Zhu, W.; Kwon, B.; Bang, H. Ethical leadership and follower unethical pro-organizational behavior: A moderated mediation study. Acad. Manag. Proc. 2017, 2017, 14847. [CrossRef] 
76. Grabowski, D.; Chudzicka-Czupała, A.; Chrupała-Pniak, M.; Mello, A.L.; Paruzel-Czachura, M. Work ethic and organizational commitment as conditions of unethical pro-organizational behavior: Do engaged workers break the ethical rules? Int. J. Sel. Assess. 2019, 27, 193-202. [CrossRef]

77. Hallberg, U.E.; Schaufeli, W.B. "Same same" but different? Can work engagement be discriminated from job involvement and organizational commitment? Eur. Psychol. 2006, 11, 119-127. [CrossRef]

78. Macey, W.H.; Schneider, B. The meaning of employee engagement. Ind. Organ. Psychol. 2008, 1, 3-30. [CrossRef]

79. Springer, A. Postawy wobec pracy-analiza porównawcza stosowanych pojęć. Edukacja Ekonomistów $i$ Menedżerów 2016, 39, 11-28.

80. Kalshoven, K.; van Dijk, H.; Boon, C. Why and when does ethical leadership evoke unethical follower behavior? J. Manag. Psychol. 2016, 31, 500-515. [CrossRef]

81. Avolio, B.J.; Gardner, W.L.; Walumbwa, F.O. Authentic Leadership Questionnaire (ALQ); Mind Garden Inc.: Menlo Park, CA, USA, 2007.

82. Sierpińska, L. Walidacja polskiej wersji kwestionariusza autentycznego przywództwa na potrzeby oceny autentycznego przywództwa kierowniczej kadry pielęgniarskiej krajowych oddziałów szpitalnych. Polski Merkuriusz Lekarski 2013, 25, 159-162.

83. Schaufeli, W.B.; Bakker, A.B.; Salanova, M. The measurement of work engagement with a short questionnaire: A cross-national study. Educ. Psychol. Meas. 2006, 66, 701-716. [CrossRef]

84. Kulikowski, K. Do we all agree on how to measure work engagement? Factorial validity of Utrecht work engagement scale as a standard measurement tool-A literature review. Int. J. Occup. Med. Environ. Health 2017, 30, 161-175. [CrossRef] [PubMed]

85. Hair, J.; Black, W.C.; Babin, B.; Anderson, R. Multivariate Data Analysis, 7th ed.; Pearson: London, UK, 2014.

86. McCallun, R.C.; Widaman, K.F.; Preacher, K.J.; Hong, S. Sample size in factor analysis: The role of model error. Multiv. Behav. Res. 2001, 36, 611-637. [CrossRef] [PubMed]

87. Comrey, A.L.; Lee, H.B. A First Course in Factor Analysis; Psychology Press: New York, NY, USA, 2013.

88. Robertson, I.T.; Cooper, C.L. Full engagement: The integration of employee engagement and psychological well-being. Leadersh. Organ. Dev. J. 2010, 31, 324-336. [CrossRef]

89. Stonkute, E.; Vveinhardt, J.; Sroka, W. Training the CSR sensitive mind-set: The integration of CSR into the training of business administration professionals. Sustainability 2018, 10, 754. [CrossRef]

90. Johnson, H.H.; Umphress, E.E. To help my supervisor: Identification, moral identity, and unethical pro-supervisor behavior. J. Bus. Ethics 2019, 159, 519-534. [CrossRef] 